\title{
EVALUATION OF GERIATRIC DEATHS CAUSED BY TRAFFIC ACCIDENTS: AN AUTOPSY SERIES
}

Turkish Journal of Geriatrics DOI: $10.31086 /$ tigeri.2018.64 2018;21 (4):573-578

- Turgay BÖRK'

- Abdurrahim TÜRKOĞLU1

- Mehmet TOKDEMIR ${ }^{2}$

CORRESPONDANCE

\section{Turgay BÖRK}

Firat University, Faculty of Medicine, Department

of Forensic Medicine, Elazığ, Turkey

e-mail: tbork7@hotmail.com

Received: 27/06/2018

Accepted: 09/10/2018

1 Firat University, Faculty of Medicine, Department of Forensic Medicine, Elazığ, Turkey

2 İzmir Katip Çelebi University, Faculty of

Medicine, Department of Forensic

Medicine, Izmir, Turkey

\section{Abstract}

Introduction: Increase in elderly population has been accompanied by traffic accidentrelated geriatric deaths. The aim of the present study was to evaluate the epidemiology and injury patterns of the victims.

Materials and Method: A retrospective analysis of autopsies performed by the Forensic Medicine Department of Firat University in 2008-2017 was conducted. The statements of relatives of the deceased, hospital records and autopsy reports were examined. The study included 206 patients aged $>65$ years and who died in traffic accidents.

Results: The victims comprised $75.2 \%$ males and $24.8 \%$ females (mean age $75.5 \pm 6.6$ years), among which $67 \%$ were pedestrians. In $68.4 \%$ of the victims, fatal accident occurred in residential areas, among which $83.7 \%$ were pedestrians. Accidents most frequently occurred on Friday ( $n=54,26.2 \%)$. In $144(69.9 \%)$ victims, death occurred in the hospital, and the mean hospitalization length was $69.6 \pm 183.9$ h. Intracranial traumatic changes were observed in $74.7 \%$ of the victims.

Conclusion: Traffic accident-related geriatric deaths were more frequent in pedestrians on specific days. Therefore, city planning should be implemented for the safety of pedestrians, with increased traffic control on busy days. Trainings should be conducted among drivers to raise the awareness of restricted mobility of the elderly.

Keywords: Geriatrics; Accidents, Traffic; Autopsy; Forensic medicine

(1)

\section{TRAFIK KAZASINA BAĞLI GERIATRIK ÖLÜMLERIN DEĞERLENDIRIILMESI: OTOPSI SERISI}

\section{$\ddot{O ̈ z}$}

Giriş: Toplum içindeki yaşlı nüfusun artması trafik kazalarına bağlı geriatrik ölümleri arttırmaktadır. Çalışmamızda; geriatrik ölümlerin epidemiyolojik özelliklerinin ve yaralanma paternlerinin incelenmesi amaçlandı.

Gereç ve Yöntem: Fırat Üniversitesi Adli Tıp Anabilim Dalı tarafından 2008-2017 yılları arasında yapılan otopsiler retrospektif olarak incelendi. Ölenlerin yakınlarının ifadeleri, hastane kayıtları ve otopsi tutanakları incelendi. Trafik kazası nedeniyle ölen 65 yaş ve üstündeki 206 olgu çalışmaya alındı.

Bulgular: Olguların \%75.2'si erkek, \%24.8'i kadındı. Olguların yaş ortalaması 75.5 \pm 6.6 yıl idi. Olguların \%67.0'ı yaya idi, kazaların \%68.4'i yerleşim yerinde meydana geldiği belirlendi. Yerleşim yerindeki kazaların \%83.7'si yaya kazaları olduğu belirlendi. Kazaların en sık \%26.2 (54) Cuma günü olduğu belirlendi. Olguların \%69.9'u (144) hastanede öldü, ortalama yatış süreleri $69.6 \pm 183.9$ saat idi. Olguların \%74.7'sinde kafa içi travmatik değişim görüldü.

Sonuç: Geriatrik olgularda trafik kazalarına bağlı ölümler daha çok yaya konumunda ve belirli günlerde olmaktadır. Bu nedenle yaya güvenliğini sağlayacak şehir planlamaları oluşturulmalı, özellikle yaşılıarın trafikte yoğun olduğu günlerde trafik denetimleri arttııılmalı, yaşııların hareket kısıtııığı konusunda sürücülere yönelik eğitimler verilmelidir.

Anahtar sözcükler: Geriatri; Kazalar; Trafik; Otopsi; Adli tıp 


\section{INTRODUCTION}

The global population is ageing at a disproportionately increasing rate (1). For example, in the United States, the population of elderly persons increased by $80 \%$ from 1920 to 2000 , and it has been predicted that by 2030 , $20 \%$ of the population of the United States will be aged $>65$ years (2). Particularly in developed countries, the percentage of the elderly is causing certain problems. Although most elderly die from natural causes, deaths from accidents, murders and suicides are not insignificant (3). For example, traffic accidents account for most of the non-natural geriatric deaths (4). Despite several precautions taken to prevent traffic accidents, which represent a significant public health problem, the elderly are considered at a higher risk because of their reduced physical abilities, such as restricted mobility, poor hearing and distracted attention. Therefore, further precautions must be introduced to protect the elderly from a premature death. Deaths due to traffic accidents are most often caused by intracranial traumatic changes (5). However, there is no study on geriatric traffic accidents.

The aim of the present study, therefore, was to evaluate the epidemiology and injury patterns of traffic accident-related geriatric deaths to establish new precautions that can prevent traffic accidents.

\section{MATERIALS AND METHOD}

Autopsy records of 206 individuals aged $>65$ years who died in traffic accidents in Elazig. Province were analysed. The autopsies were conducted at the Firat University Department of Forensic Medicine between 01 January, 2008 and 01 December, 2017. Following data were available: age and sex of the victim, date of the accident, role the victim (driver, passenger, or pedestrian), and site of death, hospitalization length and location of fatal injuries in the victim. Descriptive statistics are presented as mean \pm standard deviation, numbers or percentages. The data collected were analysed using the SPSS 17.0 (Statistical Package for Social Science) for Windows software program. Pearson's Chi-squared and Fisher's exact tests were used for statistical analysis. The differences were considered significant if the $p$-value was $<0.05$.

The study was approved by the Firat University Ethics Committee. (01 February, 2018, Meeting No. 03, Decision No. 10).

\section{RESULTS}

The deceased comprised 155 (75.2\%) males and 51 (24.8\%) females (mean age 75.5 \pm 6.6 : range, 6592 years).

The deaths were associated with traffic accidents: pedestrians struck by a vehicle $[n=138$ $(67.0 \%)]$ and driver or passenger within the vehicle [n=66 (33.0\%)] (Table 1).

The accidents occurred within [ $n=141(68.4 \%)]$ or outside $[n=65$ (31.6\%)] residential areas. Pedestrian accidents accounted for significantly more deaths [ $n=118(83.7 \%, p<0.05)]$ (Table 2$)$.

The circumstances of the deaths were as follows: during hospitalization $[n=71 \quad(74.0 \%)]$; at the site of accident $[n=17(17.7 \%)]$ or during transport to the hospital $[n=8(8.3 \%)]$ (Table 3). The mean hospitalization length among those who died in hospital was $69.6 \pm 183.9 \mathrm{~h}$.

The traffic accidents most often occurred on Friday ( $n=54,18.5 \%)$. The distribution of the accidents according to the day is presented in Figure 1.

More than one cause of death was determined in 166 cases. The most frequent cause of death was intracranial traumatic changes (74.7\%), including skull fractures, inter-membrane bleeding in the brain, and brain contusion-oedema. 
Table 1. Distribution of the traffic positions of the victims by gender.

\begin{tabular}{|c|c|c|c|c|c|c|c|c|}
\hline \multirow{3}{*}{ Sex } & \multicolumn{6}{|c|}{ Position in Traffic } & \multirow{2}{*}{\multicolumn{2}{|c|}{ Total }} \\
\hline & \multicolumn{2}{|c|}{ Pedestrian } & \multicolumn{2}{|c|}{ Driver } & \multicolumn{2}{|c|}{ Passenger } & & \\
\hline & Number & $\%$ & Number & $\%$ & Number & $\%$ & Number & $\%$ \\
\hline Male & 106 & 76.8 & 18 & 81.8 & 31 & 67.4 & 155 & 75.2 \\
\hline Female & 32 & 23.2 & 4 & 18.2 & 15 & 32.6 & 51 & 24.8 \\
\hline Total & 138 & 67.0 & 22 & 10.7 & 46 & 22.3 & 206 & 100.0 \\
\hline
\end{tabular}

Table 2. Distribution of accident sites according to accident type.

\begin{tabular}{|c|c|c|c|c|c|c|}
\hline \multirow{3}{*}{ Accident Types } & \multicolumn{4}{|c|}{ Accident Site } & \multirow{2}{*}{\multicolumn{2}{|c|}{ Total }} \\
\hline & \multirow{2}{*}{$\frac{\text { Residential Area }}{\text { Number }}$} & \multicolumn{3}{|c|}{ Outside Residential Area } & & \\
\hline & & $\%$ & Number & $\%$ & Number & $\%$ \\
\hline In-vehicle accidents & 23 & 16.3 & 45 & 69.2 & 68 & 67.0 \\
\hline Out of vehicle accidents & 118 & 83.7 & 20 & 30.8 & 138 & 33.0 \\
\hline Total & 141 & 68.4 & 65 & 31.6 & 206 & 100.0 \\
\hline
\end{tabular}

$X^{2}: 56.402, p<0.001$

Table 3. Distribution of accident sites according to the place of death.

\begin{tabular}{|c|c|c|c|c|c|c|}
\hline \multirow{3}{*}{ Location of Death } & \multicolumn{4}{|c|}{ Accident Site } & \multirow{2}{*}{\multicolumn{2}{|c|}{ Total }} \\
\hline & \multirow{2}{*}{$\frac{\text { Residential Area }}{\text { Number }}$} & \multicolumn{3}{|c|}{ Outside Residential Area } & & \\
\hline & & $\%$ & Number & $\%$ & Number & $\%$ \\
\hline At accident site & 27 & 19.1 & 19 & 29.2 & 46 & 22.3 \\
\hline During hospital transfer & 10 & 7.1 & 6 & 9.2 & 16 & 7.8 \\
\hline In hospital & 104 & 73.8 & 40 & 61.5 & 144 & 69.9 \\
\hline Total & 141 & 68.4 & 65 & 31.6 & 206 & 100.0 \\
\hline
\end{tabular}


Table 4. Cause of death. *

\begin{tabular}{lcc}
\hline Cause & Number & $\%$ \\
\hline Skull fractures & 84 & 40.8 \\
Bleeding between brain membranes & 150 & 72.8 \\
Brain contusion and oedema & 148 & 71.8 \\
Internal organ injury & 130 & 63.1 \\
Internal bleeding & 130 & 63.1 \\
Collapsed chest & 22 & 10.7 \\
Critical vascular injury & 26 & 12.6 \\
Critical nerve injury & 15 & 7.3 \\
Hospital complications & 7 & 3.4 \\
\hline
\end{tabular}

*Among 166 subjects, there was more than one cause of death

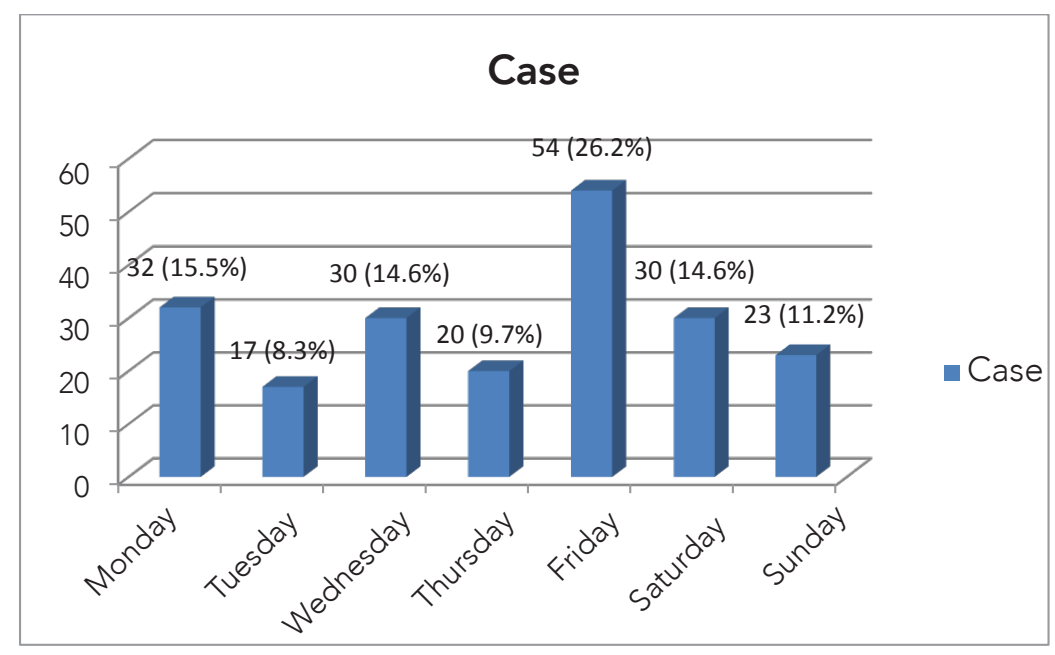

Graph 1. Distribution of cases according to the day of the week.

\section{DISCUSSION}

Two studies among elderly patients admitted to the Emergency Departments because of traffic accidents have found respectively $66.4 \%$ (6), and $62.7 \%$ (7) of the victims to be males. In the present study, $75.2 \%$ of the victims were males, which is consistent with the reported percentages. The higher percentage of males can be attributed to their more active social life in Turkey.

Old age create a significant risk to pedestrian injuries (8). Pedestrian accidents accounted for $50 \%$ of deaths of people aged $>54$ years in 
Japan (9), and most pedestrian deaths occurred among individuals aged $>75$ years in the United States (10). In the current study, $67.0 \%$ of the victims were pedestrians. The high rate of traffic accident related mortality among the elderly can be attributed to the higher frequency of elderly pedestrians and the limited use of sidewalk, footbridges or underpasses by the pedestrians. Further, drivers are not sufficiently aware of the restricted mobility of the elderly.

We found that 141 (68.4\%) and 65 (31.6\%) accidents occurred within and outside residential areas, respectively. Of the accidents occurring in residential areas, $83.7 \%$ involved pedestrian accidents, whereas of the accidents outside residential areas, $69.2 \%$ occurred within-thevehicle. The elderly are more frequently present in traffic as pedestrians, and because there is more traffic in residential areas, more pedestrian deaths occur. The accidents outside residential areas occurred at higher vehicle speeds. Therefore, the associated injuries were more severe, and deaths occurred more frequently at the accident site. When the types of accidents were evaluated according to the accident site, significantly higher deaths occurred among pedestrians $(p<0.05)$.

In the current study, 144 (69.9\%) deaths occurred in the hospital, 46 (22.3\%) at the accident site and 16 (7.8\%) during transport to the hospital. Previous studies includes all age groups have reported more frequent traffic accident-related deaths at the accident site (11). However, the mortality rate at the accident site in the current study was lower than the rates reported in other studies. This can be attributed to the relatively less severe accidents experienced by elderly pedestrians and their deaths during hospitalization. Further, the university hospital that serves our province, also receives victims of traffic accidents from surrounding areas. As the local forensic authorities performed the autopsies of transferred patients who died in the hospital, the number of deaths in the hospital was high.

Traffic accidents occur more often during weekends (12). According to TüiK data, mortal and injured traffic accidents are most common on Saturdays (13). In the current study, there were 54 (26.2\%) traffic accident-related deaths on Friday. This can be explained by the participation of the elderly population in Turkey in their Islamic religious obligations of Friday prayers at the mosque. Furthermore, Friday is the last working day of the week, and drivers may be more tired than usual, causing them to drive less carefully and to ignore the traffic rules.

Head injuries in within-vehicle and pedestrian accidents are the most common fatal injuries, and head trauma is the most common cause of traffic accident-related death (14). Ndiaye et a. have found that intracranial haemorrhage occurred most often, followed by skull fractures caused by head injuries suffered during traffic accidents (15). Toro et al. have found that when the majority of victims were pedestrians or passengers in a vehicle, skull fractures occurred in 55.4\%, intracranial haemorrhage in $42.3 \%$ and brain contusion in $53.9 \%$ (14). Consistent with the literature, in the current study, intracranial haemorrhage occurred in $72.8 \%$ brain contusion and oedema in $71.8 \%$ and internal haemorrhage and internal organ injury in $63.1 \%$ of the victims.

The results of the present study indicate that a significant proportion of traffic accidentsrelated geriatric deaths occurred in pedestrians within residential areas on specific days. City planners must, therefore, consider the safety of elderly pedestrians through the greater provision of sidewalk, increased supervision of the elderly on heavy traffic days, restrictions on vehicles in areas with a heavy concentration of pedestrians or placement of speed-limiting structures. Further, trainings should be conducted among drives to increase awareness the restricted mobility of the elderly. 


\section{REFERENCES}

1. Adam $\mathrm{SH}$, Eid $\mathrm{HO}$, Barss $\mathrm{P}$, et al. Epidemiology of geriatric trauma in United Arab Emirates. Arch Gerontol Geriatr 2008;47:377-82. (PMID:17936381).

2. Cantürk N, Cantürk G, Özdeş T, Dağalp R. Autopsies of elderly people performed between 2004 and 2006 in Ankara. Turkish Journal of Geriatrics 2009;12(4):165-70. (in Turkish).

3. Centers for Disease Control and Prevention (editorial). Motor Vehicle Traffic Related Pedestrian Deaths, United States 2001-2010. MMWR 2013;62:277-282.

4. Clarke DD, Ward P, BartlE C, Truman W. Killer crashes: fatal road traffic accidents in the UK. Accid Anal Prev 2010;42(2):764-770. (PMID:20159105).

5. Collins KA, Presnell SE. Elder homocide: a 20 year study. Am. J. Forensic Med Pathol 2006;27(2):183-7. (PMID:16738443).

6. Eser M, Keten A, İçme F, Kılınç I, Keten HS. Investigation of traffic accidents in geriatric age group. Turkish Journal of Geriatrics 2013;16(3):27780. (in Turkish).

7. Hayakawa H, Fischbeck PS, Fischhoff B. Traffic accident statistics and risk perceptions in Japan and the United States. Accid Anal Prev 2000;32(6):827-35. (PMID:10994610).

8. Kandiş H, Karakuş A, Katırcı Y, Karapolat S, Kara İH. Geriatric population and forensic traumas. Turkish Journal of Geriatrics 2011;14(3):193-8. (in Turkish).
9. Karbeyaz K, Balcı Y, Çolak E, Gündüz T. Charateristics of the traffic accidents in Eskişehir between the years 2002 and 2007. Turkiye Klinikleri J Foren Med 2009;6(2):65-73. [Internet] Available from: http:// www.turkiyeklinikleri.com/journal/adli-tip-ve-adlibilimler-dergisi/2619-9459/issue/2009/6/2-0//trindex.html Accessed: 16.04.2018. (in Turkish).

10. Massie DL, Campbell KC, Williams AF. Traffic accident involvement rates by driver age and gender. Accid Anal Prev 1995;27(1):73-87. (PMID:7718080).

11. Ndiaye A, Chambost M, Chiron M. The fatal injuries of car drivers. Forensic Sci Int 2009;184:21-7. (PMID:19111410).

12. Sardon JP. Recent demographic trends in the developed countries. Population 2006;61:197-266.

13. Towner EM. Assessment of geriatric knowledge: an online tool for appraising entering APN students. J Prof Nurs 2006;22(2):112-5. (PMID:16564477).

14. Töro K, Hubay MP. Sotonyi P, Keller E. Fatal traffic injuries among pedestrian, bicyclists and motor vehicle occupants. Forensic Sci Int 2005;151:151-6. (PMID:15939146).

15. Turkish Statistical Institute. Traffic accidents statistics. [Internet] Available from: http://www.tuik.gov.tr/ PreTablo.do?alt_id=1051 Accessed: 02.07.2018. (in Turkish). 